\title{
SOME PHASES OF MARRIAGE LAW AND LEGISLATION FROM A SANITARY AND EUGENIC STANDPOINT
}

No single institution known to modern law, not excepting that of private property, is more important from a social and economic view-point, and none, probably, reflects more numerous and complex elements, or exhibits more that is interesting in its legal history, than does marriage. It is not the present purpose, however, to discuss the history of marriage laws or marriage as an institution further than is necessary to an understanding of the character and trend of modern law and legislation on the subject, and its scope, significance, and probable efficacy from the view-point of public and individual health and morals and the preservation and betterment of the race. It may not be out of place to recall, however, that the Anglo-American law of marriage has presented, practically throughout its history: first, the common law element; second, the ecclesiastical element; and third, the statutory element, which last has, at least until comparatively recent years, been largely dominated both in its provisions and their interpretation by common law and ecclesiastical ideas; and to show, at least in a general way, that the accomplishments and possibilities of the first two elements in the interest of so-called eugenics and sexual and general prophylaxis have been by no means fully understood or exhausted, in view of the adaptability of the principle of public policy and the doctrines based upon the consensual character of marriage and the preliminary engagement to marry.

It is doubtless a rule of the common law that courts can read a principle of public policy nullifying a contract out of such statutes as relate to things collateral but germane to its subject matter. The Supreme Court of Oregon has accordingly held, that in view of local statutes having for their purpose the preven-

\footnotetext{
${ }^{1}$ We have had no ecclesiastical courts in this country. Courts of equity have quite generally assumed jurisdiction to declare marriages void for such original defects as fratud, mistake and mental incapacity. (See I Bish. Mar. Div. \& Sep. Secs. 802 et seq.) And in England since the act of 1857 this jurisdiction has been lodged in the secular courts, along with matters of separation and divorce and their usual incidents. Secs. 20 and 21 Vict. c. 85 and the Judicature Act of 1873 .
} 
tion of the spread of pulmonary tuberculosis, a man is not liable for breach of a marriage promise, even where he knew that the woman had that disease when the engagement was entered into, her ailment proving incurable. ${ }^{2}$ And by the great weight of authority in this country, if one promises in good faith to marry, but afterwards discovers that he has a disease, not due to his criminal or immoral conduct pending the engagement, unfitting him for marriage, or rendering it dangerous to himself, or to the offspring of the union, he may withdraw from the contract without liability, or insist upon postponement of performance, depending upon whether his ailment is curable or not; and so if the plaintiff contracts such disease. ${ }^{3}$

While it is quite well settled that the positive misrepresentation by the plaintiff of a material fact inducing it, will render the preliminary contract or engagement of marriage voidable, mere non-disclosure as to health, wealth, character, social position, habits, or previous history, is quite generally held to be no justification of non-performance. It would seem quite certain, however, that the non-disclosure of disease of a character that would be likely to render the marriage dangerous to the defendant, or to taint the marriage offspring, or that would be reasonably certain to frustrate its happiness, would justify the defendant's refusal to perform. ${ }^{4}$

Most of our courts would have little difficulty in applying this rule in cases of venereal disease and possibly to insanity and

\footnotetext{
${ }^{3}$ Grover v. Zook, 44 Wash. 489,7 L. R. A. (N. S.) 582, I20 Am. St. R. roI2. See also Travis v. Schnebly, 68 Wash. I, 40 L. R. A. (N. S.) 585 and note.

${ }^{3}$ Gring v. Lerch, II2 Pa. 244, 56 Am. R. 3I4; Goddard v. Westcott, 82 Mich. I80; Allen v. Baker, 86 N. Car. 9x, 4I Am. R. 444; Schackelford v. Hamilton, $93 \mathrm{Ky} .80$, I5 L. R. A. 53I, 40 Am. St. R. I66; Trammel $v$. Vaughi, I58 Mo. 2I4, 8I Am. St. R. 302, 5 I I. R. A. 854, and cases cited. Compare Smith v. Compton, 67 N. J. L. 548, 58 L. R. A. 480. The case of Hall v. Wright, El,, B1., \& El. 746, 96 E. C. L. 746, holding that a defendant in a breach of promise suit could not justify a non-performance of the contract by showing that marriage would be apt to endanger his life by reason of the development of severe hemorrhage from the lungs, has been the subject of almost universal criticism in this country. See, however, Smith v. Compton, supra.

4Atchinson v. Baker, Peake Ad. Cas. I03; Gring v. Lerch, I12 Pa. 245, 56 Am. R. 3I4; Comp. Baker v. Cartright, Io C. B. (N. S.) 124, where the prior insanity of the woman and her confinement in an asylum was held no defense. See, Travis v. Schnebly, 68 Wash. I, 40 L. R. A. (N. S.) 585 and note.
} 
tuberculosis. In fact, in cases of the former, the rule might often be invoked that a man is justified on the ground of fraud in breaking his engagement with a woman previously unchaste, where the fact was unknown to him when his promise was made, provided, of course, he acts promptly upon discovering the fact. ${ }^{b}$ Furthermore, no sufficient legal season could probably be urged why the concealment of insanity, epilepsy, or of a positive criminal history and tendencies should not, under a cautious application of the foregoing principles, be given like effect without the aid of statute. ${ }^{6}$

Alcoholism and drug addictions should likewise provide a defense, at least where they arise or are discovered pending the engagement, and this would be the only logical view where these, as in many jurisdictions, are made grounds for either limited or absolute divorce. It is hardly necessary to say that as the man is rarely plaintiff in a breach of promise suit, and as the man and not the woman is the one commonly afflicted with alcoholism or venereal disease, but little benefit to the race and but trifling increase of individual happiness can be expected from the application of these principles to alcoholism and venereal disorders in breach of promise suits.

Before leaving the subject of breach of the marriage promise, another decision of the Washington court merits attention. This is Tavis $v$. Schnebly. ${ }^{7}$ Here there was no pretense of fraud. The woman became ill without fault of either party, pending the engagement, and it was held that the mar was released therefrom, subject to the qualification that where he had consented to a postponement of performance because of her ill-health, he was bound to wait a reasonable time for her recovery. Such a decision seems a hard one for the woman, but is it not as reasonable to hold that a right-minded woman whose condition had become such that she could not be a helpmate for the man, even if she could bear him healthy children, should release him from his promise, as to hold that he should submit to the ruin of his domestic

s Burnett v. Simpkins, 24 IIl. 264; Snoreman v. Wardell, $32 \mathrm{Me} .275$; Espey v. Jones, 37 Ala. 379; Bell v. Eaton, 28 Ind. 468, 92 Am. D. 329.

- See I Bish. Mar. Div. \& Sep. 220, 22r, criticising Baker v. Cartright, supra. A collection of cases on ill-health as a defense in breach of promise cases see the note to Grover v. Zook, in 7 L. R. A. (N. S.) 582, and article in I6 Harv. L. Rev. 226, recommending a classification of diseases for purposes of defense.

${ }^{7} 68$ Wash. I, 40 L. R. A. (N. S.) 585. 
future or pay damages for his refusal to do so. That "a man does not marry a woman for the pleasure of paying for her board and washing," savors of the brutally practical, but we should remember the tendency of unhappy marriages to produce immorality within the marriage tie, and that much that is cogent has been urged by jurists and philosophers against permitting breach of promise suits at all. Should it not be held therefore that there is an implied condition in every contract to marry, that any change in the physical or mental condition of the parties, or either of them, that would practically frustrate the purposes of the marriage, will warrant rescission ? $^{8}$

Perhaps considerable can also be expected from a progressive and intelligent application of common law and equity principles and precedents in matters of divorce or technical nullity. The chief difficulty, of course, is that legal interference in such cases usually comes too late to save the plaintiff from infection, or children from hereditary taint, and that once marriage is entered into, considerations of affection, pride, religion, and the dread of scandal too often lead to passive acceptance of conditions justifying legal relief, and the continuance of a relation that ought never to have been formed. Still, a brief resumé of the principles of the unwritten law of this subject may be of some value.

At common law, the marriage of an idiot was absolutely void. This was also the rule of the canon and the ecclesiastical laws, which classed both idiocy and insanity proper, where the latter impeded marriage, as diriment impediments, as distinguished from the purely canonical ones. ${ }^{9}$ Substantially as in contract generally, the test of mental competency for marriage has been based by the common law courts and the ecclesiastical and chancery courts, upon the ability to comprehend the nature of the relation formed, and, at least in a general way, its ordinary consequences. ${ }^{10}$ If this test was fulfilled it apparently made no difference that one or both parties were feeble-minded so long as no fraud was practiced, or that either or both parties were clearly insane from a

${ }^{8}$ See the dictum in Wanecek v. Kratny, 69 Neb. 770,66 L. R. A. 798.

- See I Bish. Mar. Div. \& Sep., sec. 588 et seq.

${ }^{10}$ Portsmouth v. Portsmouth, I Hagg. Ecc. 355, 3 Eng. Ecc. 154; Durham v. Durhan, Io P. D. 80; Hunter v. Edny, to P. D. 93 ; Orchardson v. Colfield, I7I I1l. I4, 63 Am. St. R. 2II, 40 L. R. A. 256; Lewis v. Lewis, 44 Minn. I24, 20 Am. St. R. 559, 9 L. R. A. 505; Kern v. Kerm, 5 I N. J. Eq. 574; St. George v. Biddlefor, $76 \mathrm{Me}$. 593; Nonnemacher v. Nonnemacher, I59 Pa. 634; Ward v. Dulaney, 23 Miss. 4 I4. 
medical standpoint, or that the insanity was of a nature likely to taint the offspring. Neither party could attack the marriage on the ground of the mental condition of either.

The only physical or psychological condition short of idiocy or insanity that constituted an impediment to marriage, by the English ecclesiastical law, was impotency. By that law, which has furnished generally our interpretations of divorce and nullity statutes and a basis to some extent for chancery relief, this consisted in such practically incurable physical or psychological defect or peculiarity as precluded normal sexual relations between the parties. It was originally a purely canonical impediment authorizing a decree of nullity in the ecclesiastical courts, and it has been held in this country that chancery has no inherent power to pronounce a decree of nullity for this cause without the aid of statute, even where the defendant was guilty of fraudulent concealment with respect to it. ${ }^{11}$

Impotency, however, under ordinary circumstances, though an almost universal ground for nullity or divorce, has but little strictly eugenic significance, for it precludes the possibility of offspring. If, however, the existence of, venereal or other communicable or transmissible disease can be treated as impotency, the reverse is of course true. The courts, however, have not gone very far in so declaring it. True, at least one court has apparently held that incurable syphilis constitutes impotency or physical incapacity, within the meaning of the law, though its concealment also constitutes a fraud, ${ }^{12}$ and most of the cases on this subject involve concealment or misrepresentation as to the disease, and are based more or less plainly upon the ground of fraud alone. ${ }^{13}$

\footnotetext{
${ }^{11}$ See Anon. 24 N. J. Eq. I9; Burtis v. Burtis, I Hopk. Ch. (N. Y.) 557, I4 Am. D. 563; Benton v. Benton, I Day (Conn.) IIr, II4; compare Gould v. Gould, 78 Conn. 242, 2 L. R. A. (N. S.) 53I.

${ }^{12}$ Ryder v. Ryder, 66 Vt. I58, 44 Am. St. R. 833.

${ }^{13}$ Ryder v. Ryder, supra; Hooe v. Hooe, I22 Ky. 590, 5 L. R. A. (N. S.) 729; Smith v. Smith, I7I Mass. 404, 68 Am. St. R. 440, 4I L. R. A. 800; Crane v. Crane, 62 N. J. Eq. 2I; Stevenson v. Stevenson, I78 N. Y. 54; $C-v . C-, 158$ Wis. 301 . Compare Vondal v. Vondal, 175 Mass. $383,78 \mathrm{Am}$. St. R. 50, where a decree was refused, the disease (syphilis) being in a non-contagious stage, and probably curable, though it might be transmitted to offspring. There had been four months cohabitation, and the decision 'seems to have rested upon the ground of ratification or condonation. But see on this last point Hooe v. Hooe, supra, and note thereto in 5 I. R. A. (N. S.) $729 ; C-v . C-$, supra.
} 
Turning definitely to the subject of fraud, it may be said that upon principles of public policy, the courts have generally been very reluctant save in the strongest cases to pronounce a decree of nullity of marriage on that ground, with or without the aid of ordinary statutes, particularly after consummation and the birth of issue. Generally the fraud must, unless perhaps in New York, be in what are termed the essentalia of the marriage. Precisely what is meant by this term, we are not yet clearly informed. Certainly mere wealth, character or social position are not of these. Neither, with the exception of venereal disease, as above indicated, has concealment or misrepresentation touching health been generally deemed such a fraud as would warrant a decree of nullity. ${ }^{14}$

In New York, however, the principles of fraud have been applied rather more liberally than elsewhere, and the marriage of an habitual criminal was annulled where he had represented himself to be an honest and industrious man. There was no consummation. ${ }^{15}$ In another case, the marriage was annulled where the defendant, though known as a respectable person, was a thief and professional gambler. There was consummation, but no issue. ${ }^{16}$

Down to very recent years, legal restrictions upon the power, right or capacity to marry have seldom had any conscious eugenic basis. True, ecclesiastical and legislative restrictions upon the marriage of those nearly related in blood have frequently been defended upon the ground that such unions tended to produce weak and degenerate offspring, but their original basis has doubtless been largely scriptural or traditional or founded upon more or less vague notions of general morality and social convenience. Furthermore, such restrictions create a relative and not an absolute impediment at most. ${ }^{17}$ Statutes against miscegenation found

\footnotetext{
${ }^{14}$ Ewing v. Wheatley, 2 Hagg Ecc. I75; Scott v. Seabright, I2 P. D. 21; Lewis v. Lewris, 44 Minn. 124, 9 L. R. A. 505, 20 Am. St. R. 559; Cummington v. Belchertozen, I49 Mass. 223, 4 L. R. A. I3I; Wier v. Still, 3I Iowa I07; Varney v. Varney, 52 Wis. 120, I26; Lyon v. Lyon, 230 Ill. 366, 12 Am. \& Eng. Ann. Cas. 25 and note.

${ }^{15}$ Keys v. Keys, 6 Misc. 355.

${ }^{18}$ King $v$. Brewer, 8 Misc. 587. See Di Lorenzo v. Di Lorenzo, I74 N. Y. 467,63 L. R. A. 92, 95 Am. St. R. 609, and statutes and decisions cited and discussed, for the legal policy in New York.

${ }^{17}$ Recent legislation in Wisconsin and several other states where they were previously permitted, making first cousin marriages illegal, are doubtless based mainly upon the eugenic idea. On the whole, this restriction is probably wise, aithough it is undeniable that such close matings often tend to perpetuate the desirable traits of a strong stock. See Bulletin No. 9, Eugenics Record Office.
} 
in many of our states have also been defended on the ground that they save both races from deterioration, physical and moral, through both heredity and association. At any rate the constitutionality of race restrictions upon marriage or sexual relations has seldom been seriously questioned, so long as no discrimination was made between the races as to legal penalties or consequences. ${ }^{18}$

Turning definitely to the so-called eugenic marriage legislation of the last few years, it may be stated at the outset that though marriage, generally speaking, is a matter of general or common right, it is so firmly bound up with the very life of the state and with its social, moral and economic welfare as to be distinctively and preëminently within the police power. So long. as laws for its regulation can find reasonable justification as public health measures in the interest of those now living or of posterity, or as promotive of public order and morality and the: protection of individuals from fraud and injury, they will doubtless be upheld as a constitutional exercise of this power. The scope of such legislation within those limits will therefore be largely a question of public and legislative wisdom and policy, and not of constitutional law or the limitation of police power, whether the basic idea of such legislation be the protection of one spouse from bodily harm, or the protection of the public or posterity through the prevention of diseased or degenerate offspring. ${ }^{10}$

Interesting in this connection, if for no other reason than that it involved the constitutionality and construction of a most radical type of legislation, is Peterson v. Widule. ${ }^{20}$ It involved Chapter 738 of the Laws of Wisconsin for I9I3, being $\$ 2339 \mathrm{~m}$. Statutes of Wis. for I9I3. This law, which has since been amended, appears to have been the most drastic in some respects of the recent marriage acts making a medical examination prerequisite to the lawful celebration of marriage. Some comment on this case seems desirable, therefore, though no critical review of it can be attempted. It is interesting here to note, however, that by the consenstis of popular and legal opinion, in spite of

\footnotetext{
${ }^{13}$ See Freund, Police Power, sec. 675 a. See Bulletin No. 9, Eugenics. Record Office, and statutes of nearly two-thirds of our states.

${ }^{10}$ See Freund, Police Power, secs. 124, 679; Peterson v. Widule, 157 Wis. 64I (I9I4); Gould v. Gould, 78 Conn. 242, 2 L. R. A. (N. S.) 53 I and note to the same case in I9 Harv. L. Rev. 298.

${ }^{20}$ Supra.
} 
the elaborate provisions for ceremonial marriage long existing in that state, and in spite of the so-called Eugenic Marriage Law involved in this case, informal marriage per verba de praesenti, at least if followed by cohabitation, was valid as at common law in Wisconsin and is valid under the less drastic act of $1915^{21}$

The law of Igr 3 so far as material to the decision in Peterson v. Widule was substantially as follows:

"I. All male persons making application for license to marry shall . . . be examined as to the existence or nonexistence in such person of any venereal disease, and it shall be unlawful for the county clerk of any county to issue a license to marry to any person who fails to present and file with such county clerk a certificate setting forth that such person is free from acquired venereal diseases so nearly as can be determined by physical examination and by the application of the recognized clinical and laboratory tests of scientific search.

(Here follows the prescribed form of physicians' 'certificate which recites that the party is free from all venereal diseases.)

"2. Such examiners shall be physicians duly licensed to practice in this state, shall be persons of good moral character and of scientific attainments and at least thirty years of age. The fee for such examinations, to be paid by the applicant for examination before the certificate shall be granted, shall not exceed three dollars. The county physician of any county shall make the examination, if said applicant be indigent.

"3. Whenever there is a dispute or disagreement regarding the findings of any medical examiner, laboratory tests shall be made in the state laboratory of hygiene from material submitted by such examiner, and the findings of the said laboratory shall be accepted as evidence of the presence or absence in the person examined of any venereal disease.

"4. (This subdivision provides for an appeal to and hearing by the county court without a jury where the certificate is alleged to be improperly withheld.)

"5. (This subdivison relates to residents leaving the state to marry.)

\footnotetext{
${ }^{21}$ Becker v. Becker, 153 Wis. 226, and authorities cited and discussed. As this case involved the validity of an alleged marriage contracted in I898, the effect of the law of I9I3 was not involved. It may be supposed, however, that the latter law would be treated as directory rather than mandatory, particularly in view of the fact that its severe penalties are denounced against licensing officers, physicians and those-disclosing facts relating to the examination, and not against the marrying parties themselves.
} 
"6. and 7. (These subdivisons prescribed heavy penalties to county clerks for issuing licenses without the physician's certificate, to physicians for issuing false certificates, and to persons disclosing information relative to the examination.)"

In mandamus against the county clerk for refusal to issue a marriage license without the medical certificate prescribed by the act, its constitutionality was attacked upon several grounds. It was upheld, however, by five out of a bench of seven, at the expense, so many think, of its partial emasculation, a work which the legislature has since confirmed. Ignoring some elementary though fundamental propositions laid down by the court, it was held that the direction of the law against males only did not, in view of the prevalence of venereal disease among them, and its comparative rarity among women seeking matrimony, render it unreasonable and arbitrarily discriminatory, nor did it interfere in any respect with religious liberty. It was further held that the first subdivision of the act did not require freedom from all venereal disease in accordance with the certificate prescribed by the act, but freedom only from acquired as distinguished from inherited disease; and that the phrase "clinical and laboratory tests of scientific search" when construed with subdivision two of the act, fixing the fee for such examination at three dollars, did not require the Wasserman test for syphilis, which could not be made without special equipment which only a small proportion of physicians in the state possessed, and only for a fee far in excess of that prescribed; but that the law must be construed to require only such an examination as the ordinary physician could be expected to make for the fee provided by law. That the law could be upheld only by resort to a strained and unnatural construction of the language employed seems obvious; that the court was torn by contending emotions in upholding it seems equally clear.

In concluding these remarks upon the Wisconsin Law, it may be interesting to note that among the substituted bills presented to the legislature of Wisconsin now in session, was one said to have originated with a committee of the State Medical Association, preserving many of the features of the law of I9I3, but including "active pulmonary tuberculosis" and "communicable (instead of acquired) venereal disease"; applying the law to both sexes; making the certificate of "a reputable licensed physician" sufficient without regard to his age; increasing his 
fee to five dollars, and substituting "usual and ordinary tests and methods of examination" for the phrase, "recognized chemical and laboratory tests of scientific search." This bill, it can readily be seen, was in some respects more sweeping and drastic than the act of I9I3, and more nearly eugenic in the proper sense of the term. However, it failed of passage. That it well reflects the thought and sentiment of the medical profession generally is open to doubt. The average physician knows only too well that next to the instinct and craving for food, the instinct and cravings of sex are the strongest that actuate the race, and that sweeping and drastic reforms placing a practical ban upon marriage for any considerable number of the people are quite certain to increase sexual immorality even if the evils stop with the direct and familiar concomitants of vice and loose sexual connections. Speaking of tuberculosis, a leading authority on that subject says:

"While it is perfectly simple to assert, from a theoretic point of view, that the tuberculous should not be permitted to marry, the situation is entirely different when regarded from a practical standpoint. Many assume the matrimonial obligations without entertaining the remotest idea of their condition, while in others the first manifestations of a disease previously latent appear some months after marriage, or immediately following parturition. The sweeping prohibition of marriage for consumptives as a class must be regarded as both impracticable and unwarranted. A problem so delicate can never be fairly adjusted by recourse to arbitrary legal enactments based upon the medical principles of marriage selection and the social aspect of procreation. More properly it is within the province of the physician in his professional capacity to exert such an influence as may be indicated in his own judgment according to the individual circumstances." ${ }^{22}$

Beyond this it seems to be conceded that though true hereditary tuberculosis unquestionably occurs, the number of cases is practically negligible. So far as this disease is concerned, therefore, post-marital infection of the healthy spouse or post-natal infection of the children is practically all that prohibition of marriage by the tuberculous would directly accomplish, beyond a possible diminution of the birth rate of children of lower vitality than parental freedom from tubercular disease implies.

\footnotetext{
$\simeq$ See Bonney-Pulmonary Tuberculosis, and its Complications, pp.
} $595,596$. 
The Wisconsin Medical Association bill, as already stated, failed of passage and the act of I9I3 was amended by Chapter 525 of the Laws of I9I5. This chapter confines the examination and a certificate of freedom of the male from venereal disease as prerequisites to license, fixes the examiner's fee at $\$ 2.00$, puts recognized chemical and laboratory tests of scientific search within the discretion of the examining physician, and provides that microscopic tests for gonococci shall be made by the State Laboratory of Hygiene and the Wasserman test for syphilis shall be made by the Psychiatric Institute, free of charge. Any licensed physician may act and the certificate is simply of a thorough examination and the examiner's belief in freedom from all venereal diseases. The penalties against physicians and county clerks and persons making disclosure are much reduced. The conviction of a physician for issuing a false certificate would of course be extremely difficult under this law. Nullity is the penalty of evasive marriage out of the state. ${ }^{23}$ So far as venereal disease is concerned the views of the medical men are more radical than with respect to other disorders, and this act will probably have their quite general support. But until we can provide lock hospitals or other means of quarantine for venereal patients, many of them have little faith in this prohibitive legislation as a direct means of diminishing the communication and transmission of venereal disease. Medical men, however, seem generally to concede to marriage legislation of this kind an educational value, as calling attention to the prevalence of venereal and other transmissible diseases, and their grave and far reaching consequences to individuals and the race. Beyond this, however, they appear to deem it wholly experimental, and would generally oppose its extension beyond venereal disease, and possible tuberculosis, until it can be ascertained how effectively it works out. The Wisconsin law makes no provision so far as we know for reports by examining physicians of certificates of health refused under the law, though physicians are required by a preexxisting statute to report venereal disease generally, without in any way disclosing the identity of the patient. It seems impossible at present, therefore, to ascertain, even partially, how far Wisconsin legislation has really prevented the marriage of the diseased.

Perhaps the strongest argument in favor of legislation of this type is, that men who know or suspect that they have venereal

${ }^{23}$ Chapter 270, Laws of I9I5. 
disease will refrain from marriage until they are confident that they can meet the statutory medical test; that young men may be restrained from impure conduct when they know that its consequence may mean forfeiture or suspension of the right to form legitimate domestic ties, and that the public generally will be impressed with the gravity of venereal disorders, and the importance of sound health in relation to marriage and propagation from the very presence of such legislation upon the statute books.

That such laws will often be evaded is but feeble argument against them. At the same time it would seem that the existence of common law marriage side by side with such drastic legislation is not only direct invitation to its evasion but is ridiculous in itself. There is, of course, no means of estimating the number of common law marriages contracted in Wisconsin since the act of I9r3, but they are doubtless quite numerous, and their inconvenient consequences will at some time very likely be felt. The writer remembers having clipped a paid item from a Milwaukee newspaper soon after the passage of that act, to the effect that "competent attorneys" were prepared to draft binding contracts for all who desired to marry on the basis of the common law.

Many intelligent people both within and without the learned professions may be pardoned for believing for reasons already stated, for the reasons, or some of them, urged in Peterson $v$. Widule, particularly in the concurring opinion of Justice Timlin and the dissenting opinion of Justice Marshall, and for other reasons still, including our present want of scientific knowledge of much that concerns human life, particularly as applied to sex relations and propagation, that legislation of the character just considered is untimely and unwise, and that education rather than legislation must be chiefly looked to for the renovation and saving of the race through wiser choice and greater self denial in marriage. Those who maintain these views do not necessarily hold a brief against sterilization of the feeble-minded, certain classes of the insane, and the manifestly criminal and degenerate, under proper restrictions. Indeed many of them do not fail to recognize that among these, particularly the feeble-minded, the tendency toward extra matrimonial propagation is greater than among normals, owing, among other things, to their want of sex control. Segregation, asexualization and sterilization, rather than prohibition of marriage, are the only effective safeguards to society, so far as such persons are concerned. 
Finally it should be noted that Wisconsin has not been the pioneer or alone in legislation prohibiting the marriage of the unfit. Michigan has long had a law prohibiting the marriage of insane persons, idiots, or persons afflicted with syphilis or gonorrhea. This act probably adds little or nothing to the prior law so far as idiocy or insanity are concerned., No medical examination is provided for, but severe penalties are directed against persons marrying who are afflicted with venereal disease, and husband and wife are made competent witnesses for the state. The absence of a medical examination and certificate doubtless rendered this act of little practical value. ${ }^{24}$

The Connecticut statute (Chap. 325, Pub. Acts I895) provides that no man or woman, either of whom is epileptic, imbecile or feeble-minded shall intermarry or live together as husband or wife when the woman is under forty-five years of age. Any person violating or attempting to violate any of the provisions of this section shall be imprisoned in the state prison not less than three years. This statute was held constitutional, though it was held in the same case that the marriage of an epileptic in defiance of it was voidable on the ground of fraud in concealing the fact from the plaintiff, but not void. ${ }^{25}$

In Indiana no license to marry shall be issued where either of the parties is an imbecile, epileptic or of unsound mind, or under guardianship as a person of unsound mind, nor to any male who has been within five years an inmate of any county asylum or home for indigent persons, unless it satisfactorily appears that the cause of such condition has been removed and that such male applicant is able to support a family and is likely to so continue, nor shall any license issue when either of the contracting parties is afflicted with a transmissible disease, or at the time of making application is under the influence of an intoxicating liquor or narcotic drug.

\footnotetext{
${ }^{24}$ Pub. Acts of Mich. for 1899 , p. 387. The law has been strengthened somewhat by the act of 1905 which requires a physician's certificate of cure and improbability of transmission of disease or defects before any person who has been confined in a public institution as insane, epileptic, feeble minded or imbecile, shall be licensed to marry. The act does not reach patients in private institutions or in their houses.

${ }^{25}$ Gould v. Gould, 78 Conn. 242, 2 L. R. A. (N. S.) 53I. For statutes of somewhat similar import, see Chap. 234, Laws of Minn. 190r; Kans. Laws of I903, ch. 220. See also statutes in Delaware, District of Columbia, Maine, New Jersey, Ohio, Rhode Island.
} 
Provision is made for the immediate certification of the matter to the circuit court in case license is refused, and an immediate hearing without affirmative action by the applicant.

Nullity is the penalty for an evasive marriage out of the state. The penalty for a false statement procuring license is a fine not to exceed five hundred dollars. ${ }^{26}$

The Oregon act requires a physician's certificate that the male person is free from contagious or infectious venereal disease before license shall issue. Perjury by the physician is punished by revocation of his license. The fee is two dollars and a half, but those who are without the price, but are nevertheless enthusiastic about marriage, may apply to the county physician. Nothing is said about the character of the medical examination. ${ }^{27}$

In Utah marriages are prohibited and declared void when contracted with an idiot, lunatic or person afflicted with syphilis or gonorrhea, that is uncured, or with a person afflicted with chronic epileptic fits, provided the last qualification shall not apply to a female over the age of forty-five years. ${ }^{28}$

The Washington statute is perhaps as sweeping as any on the subject. It provides that no woman under the age of forty-five years and man of any age, except he shall marry a woman over forty-five years, either of whom is a common drunkard, habitual criminal, epileptic, imbecile, feeble-minded person, idiot or insane person, or person who has theretofore been afflicted with hereditary insanity, or is afflicted with pulmonary tuberculosis in its advanced stages, or any contagious venereal disease, shall thereafter intermarry or marry any other person within this state.

As to all but venereal disease, the woman as well as the man must present a physician's sworn certificate of freedom from the diseases or defects enumerated. The man only must show freedom from contagious venereal disease.

The penalties for wilful violation of the law are severe. ${ }^{20}$

The Minnesota Marriage Act authorizes the solemnization of marriage by the Superintendent of the Department of the Deaf

${ }^{28}$ Chap. 126, Laws of Ind. 1905. A very similar law is found in Pennsylvania Laws of I9I3, Chap. 458.

${ }^{2}$ Chap. 187, Laws of rgr3.

${ }^{23}$ Laws of 1909, chap. I09.

${ }^{22}$ Chap. 174, Laws of 1909. See also chap. 207, Laws of N. Dak. 1913; and see statutes of Oklahoma. Chapter I98, Laws of Vermont for 19I5, makes it a misdemeanor for persons afflicted with venereal disease to marry. The penalties for violation of the law are quite heavy. 
and Dumb in the State Deaf, Dumb and Blind Institute. A similar law is found in Ohio. Why legislatures should deem it necessary or expedient to facilitate the marriage in these institutions it is difficult to imagine, in view of the fact that congenital deaf-mutism, at least where both parties are defective, is very apt to be perpetuated in the offspring. ${ }^{30}$ We know of no state where such marriages are prohibited.

Some changes may have been made at recent sessions of the legislatures in some of the statutes above cited or commented upon, but nearly all of them still stand as indicated. ${ }^{31}$

In examining the statutes we find frequent prohibition in general terms of marriage with idiots, imbeciles, persons of unsound mind, lunatics, or insane persons. How much, if anything, these statutes add to the unwritten law of the subject is open to doubt. If they are to be construed to apply to all insane persons, lunatics, or persons of unsound mind, including those who have capacity for assent as well as to those who have not, their wisdom may well be questioned. If they add nothing to the common law they are innocuous save that so long as they remain unconstrued, they leave an important matter in doubt. It is only in a few states that laws directed toward the insane and epileptic take account of kinds or degrees, or make any attempt at definition or classification. Only two states forbid under any condition the marriage of those who have been insane. ${ }^{32}$ Though a patient may have recovered from an insanity or other psychosis, his or her marriage may be highly dangerous from an eugenic standpoint, while one suffering from traumatic insanity may run little or no risk of transmitting the affliction to offspring. Legislation against marriage of the insane as it at present exists is probably productive of very little good, not only because the legislation itself is grossly defective, but because most insanities have their onset after marriage and the birth of issue.

After all has been said, the fact remains that all laws restrictive of marriage on account of physical or mental diseases or defects will be practically dead letters unless they effectively provide for a proper medical examination as a prerequisite to license or celebration. The fact also remains, that perhaps venereal disease aside, laws of the latter sort will be unpopular for

${ }^{\text {so }}$ See Special Reports on the Blind and Deaf, Census Bureau Igoo.

${ }^{37}$ For American legislation down to June, I9I3, see Bulletin No. 9 of the Eugenics Record Office.

${ }^{8}$ See the statutes in Michigan and Washington already quoted. 
some time to come. Furthermore, as a recent writer says, "no cheap device of a law against marriage will take the place of compulsory segregation of gross defectives." They should be eliminated from the eugenic problem by segregation during the reproductive period, or by sterilization as a last resort.

Finally, marriage, which implies the home and the home and family ties, is not merely the conservator of sex morality, and by that means a quasi guardian of the public health, but it is the greatest incentive to most that is best in human endeavor and the soul and center of all that is finest and sweetest in human life. In and of itself it tends to strengthen rather than to weaken those traits and characteristics of the individual which make for health and usefulness through happiness and right living. Legislation we must indeed have for its regulation, but let that legislation be based conservatively upon the firm ground of ascertained facts and not upon the opinions of the ignorant faddist, or the rash conclusions of the pseudo reformer to whom legislation is always the proper poultice for every social sore.

MilwaukeE, Wis.

EdWard W. Spencer. 